\title{
Use of Cetaceans as Bait in Southern Bahia, Brazil, by Expert Fishermen that Market Shark Fins: A Lucrative Trade and Two Threatened Zoological Groups
}

\author{
Márcio L. V. Barbosa-Filho ${ }^{1,2}$, Rebeca M. F. Barreto ${ }^{3}$, Salvatore Siciliano ${ }^{4}$, Cecilia I. Seminara ${ }^{{ }^{*}}$, and Eraldo M. Costa-Neto ${ }^{5}$ \\ ${ }^{1}$ Programa de Pós-graduação em Zoologia, Campus Universitário Soane Nazaré, Universidade Estadual de Santa Cruz, Ilhéus, \\ BA, Brazil. ${ }^{2}$ Programa de Pós-graduação em Etnobiologia e Conservação da Natureza, Campus Dois Irmãos, Universidade \\ Federal Rural de Pernambuco, Recife, PE, Brazil. ${ }^{3}$ Colegiado de Ciências Biológicas, Universidade Federal do Vale do São \\ Francisco, Petrolina, PE, Brazil. ${ }^{4}$ Fundação Oswaldo Cruz, Laboratório de Enterobactérias (Labent), Rio de Janeiro, RJ, Brazil. \\ ${ }^{5}$ Departamento de Ciências Biológicas, Universidade Estadual de Feira de Santana, Feira de Santana, BA, Brazil. \\ ceciseminara@gmail.com
}

\begin{abstract}
In Brazil, despite the existence of a federal law prohibiting the capture and harassment of marine mammals, the use of fat as fishing bait has been reported. However, the processes of obtaining and using bait have not been described for southern Bahia state. The objective of this study was to learn how these processes occur in populations of fishermen along the southern coast of the state and how to minimize the negative impacts on the cetacean population. Semi-structured interviews about shark fishing and use of cetaceans as bait were conducted with 65 shark fishers from Ilhéus, Una, and Canavieiras municipalities in Brazil. Data were analyzed using descriptive statistics with percentage distributions. Fishermen emphasized the adipose tissue of dolphins, whales, and porpoises as preferred bait for catching sharks. Of our sample, $81.5 \%$ of fishers knew about the use of fat as bait and $56.9 \%$ knew someone who had caught cetaceans. Regarding beached whales, $67.7 \%$ reported knowing of their use and $20 \%$ had used them. This study shows the interrelation of people's use of two zoological groups: cetaceans as bait, which represents a threat to the group, and sharks for commercialization, a group in which $75 \%$ of species are endangered. It shows the ecological impacts of these interactions. Protection measures will only be effective when they approach the local culture in an integrated manner by considering traditional customs that have developed from centuries of exploitation.
\end{abstract}

Received March 31, 2017

OPEN ठACCESS

Accepted July 17, 2017

DOI 10.14237/ebl.9.2.2018.953

Keywords Ethnobiology, Ethnoecology, Artisanal fishing, Shark fishing, Cetacea

Copyright (c) 2018 by the author(s); licensee Society of Ethnobiology. This is an open-access article distributed under the terms of the Creative Commons Attribution-NonCommercial 4.0 International Public License (https://creativecommons.org/licenses/by-nc/4.0), which permits non-commercial use, distribution, and reproduction in any medium, provided the original author and source are credited.

\section{Introduction}

Anthropogenic impacts on aquatic ecosystems are a major threat to cetaceans worldwide. Several species in this group are susceptible to pollution in aquatic environments, environmental degradation, impacts from fishing, and increase in boat traffic (Di Beneditto et al. 2010; Read 2008). Nevertheless, there is little scientific information regarding the life histories of most small cetacean species; therefore, they are listed as "data deficient" by the International Union for Conservation of Nature (Schipper et al. 2008).

Every year, hundreds of thousands of whales and dolphins are killed by intentional and incidental catches and used for commercial and subsistence purposes (Read 2008; Robards and Reeves 2011). Robards and Reeves (2011) point out that the scenario of cetacean exploitation by humans is highly complex, geographically broad, taxonomically diverse, and strongly linked to cultural and economic issues.

In Brazil, small and large cetaceans have been used historically as food, bait, in traditional medicine, as energy sources, and to manufacture handicrafts and amulets (Alves and Rosa 2008; Barbosa-Filho et al. 2016a; Brum et al. 2015; Morais et al. 2016; Siciliano 1994; Tosi et al. 2009). The exploitation of large cetaceans in the country began in the seventeenth century. Historical data demonstrate that the produc- 


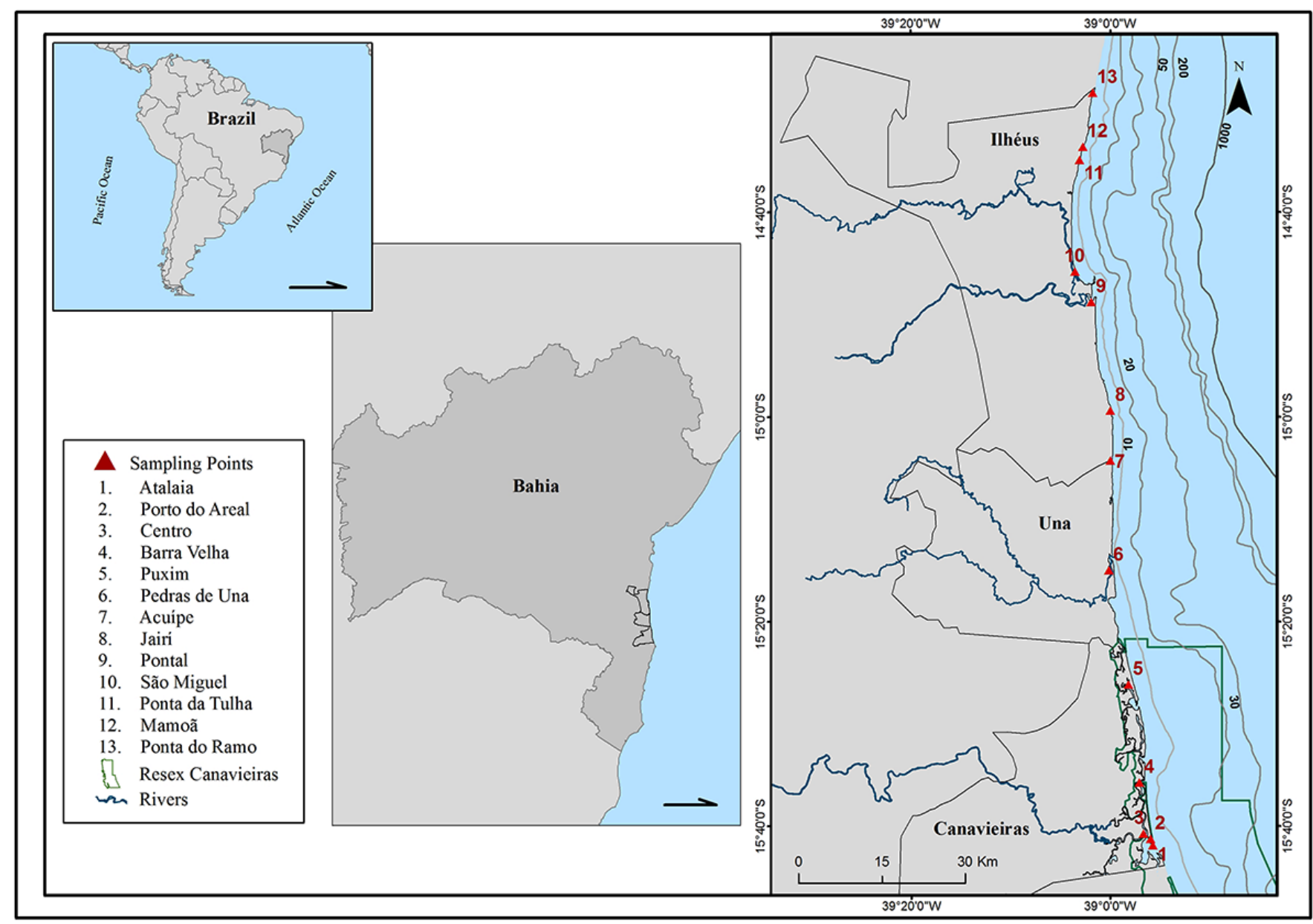

Figure $1 \mathrm{Map}$ of the surveyed area in central-south Bahia state, Brazil, showing the fishing communities where interviews were conducted.

tion of whale oil to meet the demands of the energy market was notable (Morais et al. 2016).

More recently, despite the legal prohibition of harassing and fishing all cetaceans (Federal Law No. 7643, December 1987), the use of cetacean fat as bait has been described in the scientific literature (Cosentino and Fisher 2016). In Brazil, the fat is generally used to fish for certain river species (Brum et al. 2015; Iriarte and Marmontel 2013) and sharks (Barbosa-Filho et al. 2016a; Siciliano 1994). On the other hand, obtaining this material usually occurs from incidental (Rosa et al. 2012; Zappes et al. 2009) or intentional (Barbosa-Filho et al. 2016a; Brum et al. 2015; Siciliano 1994) catches.

Siciliano (1994) recorded the use of large and small cetaceans as bait in shark fisheries along the Bahia coast. More recently, Barbosa-Filho et al. (2016a) described the practice of harpooning dolphins for use as bait in local shark fisheries, because shark fins are highly valuable (Barbosa-Filho et al. 2016b). However, contemporary processes of use and storage of incidentally captured dolphins, as well as beached whale carcasses, have not been described and discussed regionally. Thus, the present study aimed to provide answers to the following questions: (1) What are the processes for using cetacean blubber as bait among fishermen in southern Bahia? (2) How can these impacts be minimized to conserve local populations of cetaceans?

\section{Materials and methods}

Before we started collecting data, a proposal for this study was evaluated and approved (CAAE 01244412.3.0000.5526) by the Ethics Committee for Research involving Humans at the Universidade Estadual de Santa Cruz. Furthermore, considering that the research was partially conducted inside the 


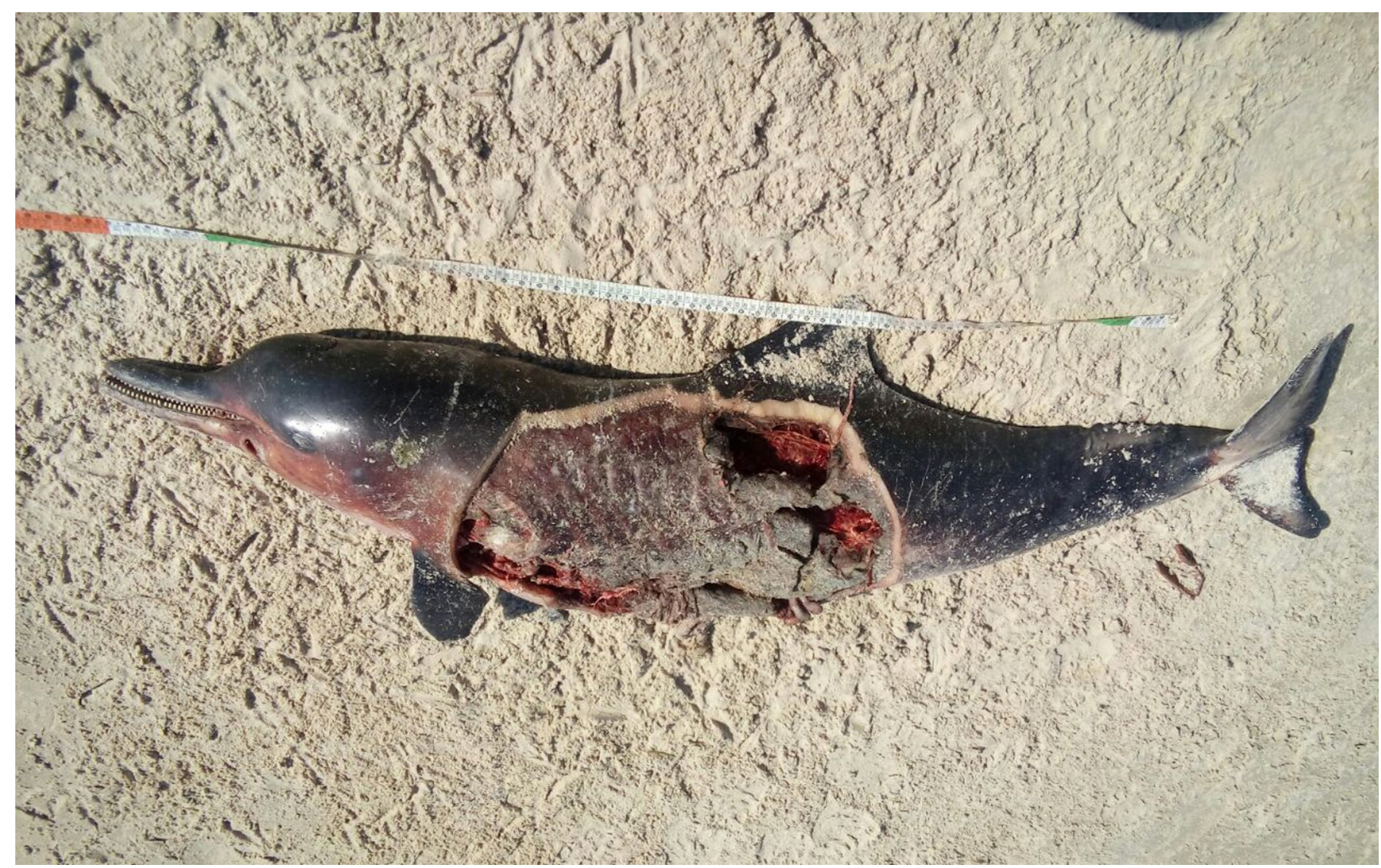

Figure 2 Guiana dolphin (Sotalia guianensis) carcass found in southern Bahia, showing removed fat, generally used as bait. Photo: Pat Ecosmar.

Canavieiras Marine Extractive Reserve, which is a federal Marine Protected Area, the project was authorized (reference \#33276-1) by the National System of Information and Authorization on Biodiversity (SISBIO). At the beginning of each interview, we informed the fishermen that his anonymity would be protected.

Data were collected by means of 65 semi-structured recorded interviews with male fishermen. All participants live in the 13 communities located in the municipalities of Ilhéus, Una, and Canavieiras in Brazil (Figure 1). The interviews focused on shark fishing, using local cetaceans as bait, and past and present uses of whale and dolphin for this purpose.

Participants were selected through simple stratified sampling (Albuquerque et al. 2014) by identifying a network of specialists (Marques 2001) that had over 15 years of experience fishing sharks locally. Other criteria for selecting interviewees included interest in participating and living in the region.
In 2013 and 2014, the principal researcher gave public lectures presenting the research results at the headquarters of the Fishermen's Associations (in Serra Grande and Atalaia), in bars where the local fishermen often meet (in the community of Queimada, at Mamoã beach, and São Miguel), at the headquarters of Colony Z-19 in Ilhéus and Colony Z-20 in Canavieiras, at a public school in the community of Acuípe, at the residence of a fisherman of the Pedras de Una community, at the headquarters of the Extractive Marine Reserve of Canavieiras, and at Porto do Areal in Canavieiras. In addition, several presentations were given to individual participants, usually at fishing piers or in their homes.

To analyze the knowledge of the fishermen, we used the model of integrating various individual competencies (Marques 2001), in which all information supplied was considered. Quantitative analysis involved descriptive statistics with percentage distributions. 


\section{Results}

Most of the fishers $(93.8 \% ; \mathrm{n}=61)$ reported the frequent practice of using fishing baits. When asked which baits do sharks prefer, the blubber of three ethnospecies of cetaceans was mentioned: $56.9 \%(\mathrm{n}=$ 37) mentioned golfinhos (dolphins), $49.2 \%(\mathrm{n}=32)$ mentioned baleias (whales), and 43.1\% $(\mathrm{n}=28)$ mentioned toninhas (porpoises).

When asked specifically about the ethnospecies of small cetaceans, $81.5 \%(n=53)$ of interviewees reported having knowledge about local use of fat as bait. Moreover, $56.9 \%(\mathrm{n}=37)$ of participants knew a fisher who had caught, intentionally or incidentally, at least one small cetacean. This fact is made explicit in participant statements:

"Dolphin bait is the one that sharks like the most." (T., 52 years old)

"The meat is red and releases an oil. The sharks go crasy ...it's with whale and dolphin that they catch the most." (W., 47 years old)

"Whale meat. Dolphin also has a lot of oil, but the best is whale bait." (F., 31 years old)

When stranded and killed in fishermen's nets, specimens of small cetaceans are chopped with knives and the fat layer is cut into small pieces to be used on hooks. According to interviewees, the animal carcasses are quickly returned to the sea because fishermen are afraid of being caught by inspectors. Thus, on some occasions, lacerated animal carcasses wash up on the beaches (Figure 2). One interviewee described how a small cetacean caught in a fishing net was used:

"They had already taken dead dolphins in the net, cut slices, and used it as bait." (B., 42 years old)

As for large beached cetaceans (locally called "whales"), the body is often chopped by the fishers with machetes to use the blubber as bait. Whales were reported to be used for this purpose by $67.7 \%(\mathrm{n}=$ 44) of informants. However, only $20 \% \quad(\mathrm{n}=13)$ admitted having used this type of blubber, while nine said they had buried pieces of fat near a beach for subsequent use. The fishermen emphasized that blubber is better when it is extremely rotten (advanced putrefaction stage) because sharks are attracted to the smell.
The process of burying the adipose tissue (blubber) of a beached whale was reported as follows: the fisher takes large pieces of fat, puts salt on them, buries them in large bags, and digs them up when needed. According to interviewees, this fat can be used up to five years after being buried. Nevertheless, there are fishermen who currently recognize the institutional prohibition of handling carcasses washed up on beaches.

Regarding sharks, 59 (89.1\%) of interviewed fishermen reported a decrease over the years in the number of these animals in the fisheries. Of these, 32 $(48.3 \%)$ reported perceiving that the fisheries of these animals had declined $80 \%$ or more. Among the main reasons reported for decreases in catches were shrimp trawling $(57.0 \% ; \mathrm{n}=37)$, catching sharks to harvest the fins $(43.0 \% ; \mathrm{n}=28)$, lobster fishing with nets $(35.0 \% ; \mathrm{n}=23)$, and excess use of gill nets $(19.0 \%$; $=12$ ). Respondents frequently complained that shrimp trawling occurred in areas and times prohibited by law.

In this context of local threats to cetacean and shark species, fishermen point out the need for more frequent inspections in the region, which they considered quite rare and ineffective.

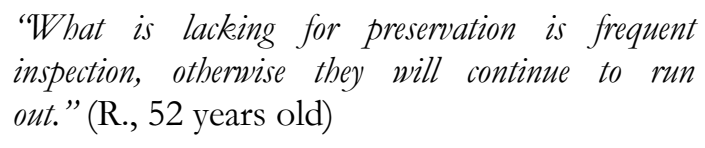

\section{Presentation of research results}

Around 200 people attended the meetings to present the study results, including fishermen, professionals who deal in some way with fishing in the region, students, and other people. Not all invited interviewees could attend the presentations. On these occasions, in addition to presenting the main interview findings, information was also presented about the ecological conditions of the main species caught in the region, impacts of some types of fishing reported in the study area, and other types of threats which directly or indirectly affect regional fishing. In addition, global data on the threat status of the main zoological groups with which fishermen interacted were highlighted in order to clarify and raise awareness among fishermen about the need to conserve marine animals. At the end of each presentation, there were discussions with the fishermen about the information presented.

There was abundant exchange of information between the researcher and participants in the 
discussions. Participants expressed satisfaction with the presentations, especially local fishermen, who complain that some researchers conduct interviews but do not return to present their results. Participants demonstrated interest in establishing a dialogue with the scientific community and government organizations to denounce predatory practices in the region and to construct alternatives that generate greater income from the fisheries in sustainable ways.

\section{Discussion}

Because catching and harassing cetaceans is prohibited in Brazil, it is possible that some of the participants in this study preferred to deny the use of cetaceans as bait. It was difficult to infer the cetacean species reported by interviewees because the common names used by Brazilian fishers refer to multiple taxa (Souza and Begossi 2007). Batista et al. (2012) monitored beaches along the coast of Ilhéus between 1997 and 2007 and recorded 36 stranded cetaceans belonging to ten species: Sotalia guianensis (17), Megaptera novaeangliae (6), Physeter macrocephalus (3), Ziphius cavirostris (3), Steno bredanensis (2), Globicephala macrorbynchus (1), Orcinus orca (1), Peponocephala electra (1), Stenella clymene (1), and Feresa attenuata (1).

Southern Bahia has a history of small scale fishing with hand lines for over four centuries (Olavo et al. 2005). Presently, this practice retains its artisanal character. Besides hand lines, fishing is done using gillnets and longlines with bait caught by the fishers (Barbosa-Filho et al. 2014). Cetacean blubber is often used as bait for longline fishing. Several studies with artisanal Brazilian fishers have reported the use of cetaceans as fishing bait (Rosa et al. 2012; Siciliano 1994; Zappes et al. 2009). In Amazonia, for example, all body parts of the Amazon river dolphin (Inia geoffrensis) are commonly used for piracatinga (Calophysus macropterus) fishing (Brum et al. 2015). Recent studies have shown that recent population declines of this small cetacean are strongly related to piracatinga fishing (Iriarte and Marmontel 2013).

Câmara (1889) reported that in the Recôncavo Baiano region, whale "ladder", a hard part of the animal's ventral region, was used as bait and when salted could be used "from year to year" to catch sharks. This report illustrates the old and recurring cultural practice of fishermen using cetaceans to catch sharks. The practice of burying pieces of whale fat had not been recorded among Brazilian artisanal fishermen.
Scientific studies have pointed out inherent health risks associated with improper handling of marine mammal carcasses (Hunt et al. 2008; Siciliano et al. 2016). Cutting up beached cetacean carcasses for bait could negatively impact their conservation by removing pieces of the carcass that could be collected for biopsies used to elucidate threats to the group (Di Beneditto et al. 2010). Rosa et al. (2012) point out that the main problems related to the conservation of small coastal cetaceans in Brazil are lack of regular monitoring of catches and beached individuals, as well as lack of knowledge about population sizes. For these reasons, the Red Book of the Brazilian Fauna Threatened with Extinction (MMA 2008) notes that fishing interactions are one of the main threats to cetaceans nationally. Therefore, environmental agencies and the academic community are expected to formulate environmental and sanitary education initiatives for local fishermen as a way to discourage them from using cetaceans that are caught incidentally or stranded on beaches.

The present study reports the use of another zoological group under strong anthropogenic pressure: the elasmobranch fish. Globally, about 75\% of the 1,041-existing species of sharks and rays are threatened with extinction (Dulvy et al. 2014). The group is also threatened along the Brazilian coast, a main global hotspot of elasmobranch diversity (Lucifora et al. 2011), mainly due to the impact of artisanal and industrial fishing (Bornatowski et al. 2014). In southern Bahia, fishing for elasmobranch species (Barbosa-Filho et al. 2014; Giglio et al. 2015) has existed for centuries and continues in different forms.

Although fishermen from southern Bahia often have refined ethnobiological knowledge about sharks (Barbosa-Filho et al. 2014; Barbosa-Filho and CostaNeto 2016), some of their environmental perceptions may continue to threaten these animals (BarbosaFilho et al. 2014). For example, some local fishermen report that sharks moved away from the southern region of Bahia because non-selective fishing diminished their local food supply (Barbosa-Filho and Costa -Neto 2016). These circumstances suggest the importance of raising awareness among local fishermen about the threats to these fish.

The present study shows the interrelation of two distinct zoological groups, cetaceans and elasmobranchs, which are closely related in the culture of marine fishing in southern Bahia. Barbosa-Filho et al. 
(2016b) argue that shark conservation requires studies about social, economic, and ecological impacts of fin commercialization by Brazilian fishermen, as well as discussions about its possible prohibition. It is also possible that a ban on the commercialization of shark fins would have positive effects on the conservation of cetacean species used as bait. It is necessary to carry out further studies to ascertain whether the educational interventions about these two zoological groups, carried out in 2013 and 2014, had measurable effects in relation to fishermen's knowledge and practices. Effective protection measures will only occur when these aspects of local culture are addressed in an integrated way, considering traditional customs that resulted from centuries of exploitation.

\section{Declarations}

Permissions: The study was approved by the Ethics Committee for Research involving Humans at Universidade Estadual de Santa Cruz (Number 01244412.3.0000.5526).

Sources of funding: M. L. V. Barbosa Filho received a master's fellowship (Number 132919/2011-7) from the Conselho Nacional de Desenvolvimento Científico e Tecnológico (CNPq).

Conflicts of Interest: None declared.

\section{References Cited}

Albuquerque, U. P., L. V. F. C. Cunha, R. F. P. Lucena, and R. R. N. Alves. 2014. Methods and Techniques in Ethnobiology and Ethnoecology. Springer, New York, NY.

Albuquerque, U. P., L. V. F. C. Cunha, R. F. P. Lucena, and R. R. N. Alves. 2014. Methods and Techniques in Ethnobiology and Ethnoecology. Springer, New York, NY.

Alves, R. R., and I. L. Rosa. 2008. Use of Tucuxi Dolphin Sotalia fluviatilis for Medicinal and Magic/ Religious Purposes in North of Brazil. Human Ecology 36:443-447. DOI:10.1007/s10745-0089174-5.

Barbosa-Filho, M. L. V., and E. M. Costa-Neto. 2016. Conhecimento Ecológico Local de Pescadores Artesanais do sul da Bahia, Brasil, sobre as Interações Tróficas de Ttubarões. Biotemas 29:4152. DOI:10.5007/2175-7925.2016v29n3p41.

Barbosa-Filho, M. L. V., A. Schiavetti, D. T. Alarcon, and E. M. Costa-Neto. 2014. "Shark is the Man!": Ethnoknowledge of Brazil's South Bahia
Fishermen Regarding Shark Behaviors. Journal of Ethnobiology and Ethnomedicine 10:54. DOI:10.1186/1746-4269-10-54.

Barbosa-Filho, M. L. V., E. M. Costa-Neto, and D. Danilewicz. 2016a. Dolphin Harpooning Off the Coast of Bahia, Brazil. Marine Biodiversity Records 9:42. DOI:10.1186/s41200-016-0046-1.

Barbosa-Filho, M. L. V., E. M. Costa-Neto, and S. Siciliano. 2016b. Knowledge and Practices of Expert Fishermen of South Bahia, Brazil, Regarding the International Shark Fin Market. Human Ecology 44:1-9. DOI:10.1007/s10745-0169873-2.

Batista, R. L. G., A. Schiavetti, U. A. Santos, and M. S. S. Reis. 2012. Cetaceans Registered on the Coast of Ilhéus (Bahia), Northeastern Brazil. Biota Neotropica 12:31-38.

Bornatowski, H., R. R. Braga, and J. R. S. Vitule. 2014. Threats to Sharks in a Developing Country: The Need for Effective and Simple Conservation Measures. Natureza and Conservação 12:11-18.

Brum, S. M., V. M. Silva, F. Rossoni, and L. Castello. 2015. Use of Dolphins and Caimans as Bait for Calophysus macropterus (Lichtenstein, 1819) (Siluriformes: Pimelodidae) in the Amazon. Journal of Applied Ichthyology 31:675-680. DOI:10.1111/ jai.12772.

Câmara, A. A. 1889. A Pesca da Balêia na Província da Bahia. Revista da Sociedade de Geographia do Rio de Janeiro. Tomo V.

Cosentino, A. M., and S. Fisher. 2016. The Utilization of Aquatic Bushmeat From Small Cetaceans and Manatees in South America and West Africa. Frontiers in Marine Science 3:163. DOI:10.3389/ fmars.2016.00163.

Di Beneditto, A. P., S. Siciliano, and R. M. A. Ramos. 2010. Cetáceos: Introdução à Biologia e a Metodologia Básica para o Desenvolvimento de Estudos. Escola Nacional de Saúde Pública/Fiocruz, Rio de Janeiro, Brasília.

Dulvy, N. K., S. L. Fowler, J. A. Musick, R. D. Cavanagh, P. M. Kyne, L. R. Harrison, J. K. Carlson, L. N. K. Davidson, S. V. Fordham, M. P. Francis, C. M. Pollock, C. A. Simpfendorfer, G. H. Burgess, K. E. Carpenter, L. J. V. Compagno, D. Ebert, C. Gibson, M. Heupel, S. Livingstone, J. Sanciangco, J. Stevens, S. Valenti, W. White. 2014. Extinction Risk and Conservation of the World's Sharks and Rays. eLife 3:e00590. 
Giglio, V. J., O. J. Luiz, and L. C. Gerhardinger. 2015. Depletion of Marine Megafauna and Shifting Baselines Among Artisanal Fishers in Eastern Brazil. Animal Conservation 18:348-358.

Hunt, T. D, M. H. Ziccardi, F. M. D. Gulland, P. K. Yochem, D. W. Hird, T. Rowles and J. A. K. Mazet. 2008. Health Risks for Marine Mammal Workers. Diseases of Aquatic Organisms 81:81-92. DOI: $10.3354 /$ dao01942.

Iriarte, V., and M. Marmontel. 2013. Insights on the Use of Dolphins (Boto, Inia Geoffrensis and Tucuxi, Sotalia Fluviatilis) for Bait in the Piracatinga (Calophysus Macropterus) Fishery in the Western Brazilian Amazon. Journal of Cetacean Research and Management 13:163-173.

Lucifora, L. O., V. B. García, and B. Worm. 2011. Global Diversity Hotspots and Conservation Priorities for Sharks. PLoS One 6:19356. DOI:10.1371/journal.pone.0019356.

Marques, J. G. W. 2001. Pescando Pescadores: Ciência e Etnociência em uma Perspectiva Ecológica. NUPAUB, São Paulo, Brasília.

MMA, Ministério do Meio Ambiente. 2008. Livro Vermelho da Fauna Brasileira Ameaçada de Extinção, edited by A. B. Machado, G. M. Drummond, and A. P. Paglia. MMA/Fundação Biodiversitas, Brasília.

Morais, I. O., D. Danilewicz, A. N. Zerbini, W. Edmundson, I. B. Hart, and G. A. Bortolotto. 2016. From the Southern Right Whale Hunting Decline to the Humpback Whaling Expansion: A Review of Whale Catch Records in the Tropical Western South Atlantic Ocean. Mammal Review 47:11-23. DOI:10.1111/mam.12073.

Olavo, G., P. A. Costa, and A. S. Martins. 2005. Caracterização da Pesca de Linha e Dinâmica das Frotas Linheiras da Bahia, Brasil. In Pesca e Potenciais de Exploração de Recursos Vivos na Região Central da Zona Econômica Exclusiva Brasileira (Série Livros n.13), edited by P. A. Costa, A. S. Martins, and G. Olavo, pp. 13-34. Museu Nacional, Rio de Janeiro, Brasília.

Read, A. J. 2008. The Looming Crisis: Interactions Between Marine Mammals and Fisheries. Journal of Mammalogy 89:541-548. DOI:10.1644/07-MAMMS-315R1.1.
Robards, M. D., and R. R. Reeves. 2011. The Global Extent and Character of Marine Mammal Consumption by Humans: 1970-2009. Biological Conservation 144:2770-2786. DOI:10.1016/ j.biocon.2011.07.034.

Rosa, G. A., C. A. Zappes, and A. P. Di Beneditto. 2012. Etnoecologia de Pequenos Cetáceos: interações Entre a Pesca Artesanal e Golfinhos no Norte do Estado do Rio de Janeiro, Brasil. Biotemas 23:293-304.

Schipper, J., J. S. Chanson, F. Chiozza, N.A. Cox, M. Hoffmann, V. Katariya, J. Lamoreux, A. S. Rodrigues, S. N. Stuart, H. J. Temple, and J. Baillie. 2008. The Status of the World's Land and Marine Mammals: Diversity, Threat, and Knowledge. Science 322:255-230. DOI:10.1126/ science.1165115.

Siciliano, S. 1994. Review of Small Cetaceans and Fishery Interactions in Coastal Waters in Brazil. Report, International Whaling Commission, United Kingdom.

Siciliano, S., M. L. V. Barbosa-Filho, and L. R. Oliveira. 2016. Human Consumption of a Vagrant South American Fur Seal Arctocephalus australis (Carnivora: Otariidae) in Brazil. Journal of Threatened Taxa 8:8728-8731. DOI:10.11609/ jott.2525.8.4.8728-8731

Souza, S. P., and A. Begossi. 2007. Whales, Dolphins or Fishes? The Ethnotaxonomy of Cetaceans in São Sebastião, Brazil. Journal of Ethnobiology and Ethnomedicine 3:9. DOI:10.1186/1746-4269-3-9.

Tosi, C. H., F. A. Magalhães, and R. G. Garri. 2009. Meat consumption of a Fraser's Dolphin (Lagenodelphis hosel) Stranded Alive on the Northern Brazilian Coast. Marine Biodiversity Records 2:4. DOI:10.1017/S1755267208000043.

Zappes, C. A., A. Andriolo, F. Oliveira, and E. L. Monteiro-Filho. 2009. Potential Conflicts Between Fishermen and Sotalia guianensis (van Bénéden, 1864) (Cetacea, Delphinidae) in Brazil. Sitientibus Série Ciências Biológicas 9:208-214. 